\title{
Assessment of bioaerosols in urban and rural primary schools using passive and active sampling methodologies
}

\author{
Nuno Canha ${ }^{1, *}$, Susana Marta Almeida ${ }^{1}$, Maria do Carmo Freitas ${ }^{1}$, Hubert Th. Wolterbeek ${ }^{2}$ \\ ${ }^{1}$ Universidade de Lisboa, Portugal \\ Instituto Superior Técnico \\ C2TN - Centro de Ciências e Tecnologias Nucleares \\ ${ }^{2}$ Delft University of Technology, The Netherlands \\ Faculty of Applied Sciences \\ Department of Radiation, Radionuclides and Reactors
}

*Corresponding author's e-mail: nunocanha@ctn.tecnico.ulisboa.pt

Keywords: primary schools, indoor air quality, bioaerosols, pollens, fungi, bacteria, urban and rural.

\begin{abstract}
People spend most of their time in indoor environments and, consequently, these environments are more significant for the contribution of the daily pollutant exposure than outdoors. In case of children, a great part of their time is spent at school. Therefore, evaluations of this microenvironment are important to assess their time-weighted exposure to air pollutants.

The aim of this study was to assess the children exposure to bioaerosols at schools from two different types of areas, urban and rural. A methodology based upon passive sampling was applied to evaluate fungi, bacteria and pollens, simultaneously with active sampling for fungi and bacterial assessment. Results showed very good correlations between sampling methods, especially for summer season. Passive sampling methodologies presented advantages such as no need of specific and expensive equipment, and they allow achieving important qualitative information.

The study was conducted in different periods of the year to study the seasonal variation of the bioaerosols. Fungi and pollen presented higher levels during the summer time whereas bacteria did not present a seasonal variation. Indoor to outdoor ratios were determined to assess the level of outdoor contamination upon the indoor environment. Levels of fungi were higher outdoor and bacteria presented higher concentrations indoors.

Indoor levels of bioaerosols were assessed in primary schools of urban and rural areas, using the active method along with a passive sampling method. Very good correlations between methods were found which allow the use of the passive sampling method to supply important and reliable qualitative information of bioaerosols concentrations in indoor environments. Seasonal variation in bioaerosols concentrations were found for fungi and pollen. Concentrations of fungi and bacteria above AMV (Acceptable Maximum Value) were found for most of the studied classrooms showing the importance of this microenvironment for the high exposure of children to bioaerosols.
\end{abstract}

\section{Introduction}

Indoor air shortcomings are one of the most common environmental issues faced nowadays by doctors in medicine (Wilson and Spengler 1996, Kosonen and Tan 2004). In fact, people spend $80-95 \%$ of their lives indoors and breathe around $10 \mathrm{~m}^{3}$ of air every day (Almeida-Silva et al. 2014a,b, 2015, Dacarro et al. 2003, Ramos et al. 2014). Therefore, indoor air pollution can result in health problems and in increase of mortality (Jantunen et al. 1997).

Children are more vulnerable to environmental pollutants compared to adults since they breathe more air relatively to their body weight and also have a lower ability to deal with the toxic chemicals due to their undeveloped airways (Selgrade et al. 2008). Therefore, in the last decade, the importance of indoor air quality in schools buildings has gathered an increased concerning from the scientific community, which is reflected by the higher amount of published studies in this very specific type of microenvironment (Almeida et al 2009a, 2011, Canha et al. 2012a,b, 2014a,b,c, Morawska et al. 2013, Pegas et al. 2010, 2011a,b, Trancoso et al. 2012).

Poor indoor air quality at classrooms was demonstrated to exert a negative impact on children's learning performance, with absenteeism and adverse health effects such as increased risk of asthma and other health-related symptoms (Canha et al. 2011, 2013b).

In schools, aerosol particles are one of the pollutants that can cause the decrease of indoor air quality. Particles may be originated naturally (e.g. dust, salt, pollen, viruses, fungi, bacteria) or from anthropogenic sources, such as industrial activity, incineration and combustion processes among others (Almeida et al. 2009b, 2012, 2013, Almeida-Silva et al. 
2011a,b, Bejan et al. 2004, Canha et al. 2010, 2012c, 2013a, Lage et al. 2014). The hazardous nature of aerosol particles appears to be related to four factors: the chemical composition and size of the particles, the duration of exposure and the particle concentration in the breathing zone of the exposed person. Bioaerosols are airbone particles that are living (bacteria, viruses and fungi) or originate from living organisms (pollens) and can contribute to about 5-34\% of the indoor air pollution (Skrikanth et al. 2008). Indoor airborne bacteria are normally associated with the presence of humans and fungi are usually imported from the outdoor environment (Burge 1995, Macher 1999, Viegas et al. 2014).

Epidemiological investigations had shown that the sick building syndrome and the hypersensivity diseases are often associated with exposure to large concentrations of airborne microbes (Pastuszka et al. 2000).

Airborne bacteria and fungi can be the cause of a variety of health effects that can be divided in five categories, namely: (i) irritative symptoms, (ii) respiratory infections, (iii) allergic diseases, (iv) alveolitis and organic dust toxic syndrome (ODTS), and (v) other chronic pulmonary diseases (e.g. chronic bronchitis) (Husman 1996).

The aim of this study was to assess the children exposure to bioaerosols (pollen, fungi and bacteria) in primary schools of two different clusters, urban and rural. Bacteria and fungi were sampled using the Petri-plate gravitational settling (passive) method (Aydogdu et al. 2005, Cabral 2010) simultaneously with the active method, while pollens were sampled using uniquely a passive deposition method.

\section{Materials and methods}

\section{Sampling site and schools description}

This study was focused in primary schools of two distinct types of areas, urban and rural, of Portugal mainland (Figure 1). In the urban area, schools from Lisbon were selected, which is the largest city of Portugal and the westernmost capital in mainland Europe. Lisbon city has a population density of 6663 inhabitants $/ \mathrm{km}^{2}$ while its metropolitan area has a population density of 976 inhabitants $/ \mathrm{km}^{2}$. In the rural area, the municipality of Ponte de Sor was selected, where primary schools of 3 villages were studied, namely Foros de Arrão, Longomel and Vale de Açor with a populational density of 12, 32 and 13 inhabitants $/ \mathrm{km}^{2}$, respectively.

All the schools have natural ventilation without any air conditioning system. The age of the students attending lessons in the studied classrooms ranged from 6 to 12 years old.

In the urban area, two classrooms were studied per school. In the rural area, only one classroom was chosen to be representative of that specific rural school since all of them had few classrooms and very similar characteristics (number of students, physical characteristics of the classrooms, and type of surfaces).

The characteristics of the studied schools are shown in Table 1. All the studied classrooms were located at the ground floor level and adjacent to the playground which had green areas with trees. Urban schools 1 and 3 are located in residential neighborhoods and urban school 2 is located near the city downtown which has high traffic intensity.

\section{Sampling}

\section{Pollen assessment}

Concerning the pollen assessment at the urban area, the study was conducted in 3 sampling campaigns, namely during the autumn of 2009, winter of 2009/2010 and spring of 2010. For the rural schools, the sampling campaign was only performed in spring season to assess possible differences between both types of areas in a specific season.

The indoor pollen concentrations were assessed by a passive sampling method through the exposure of slides

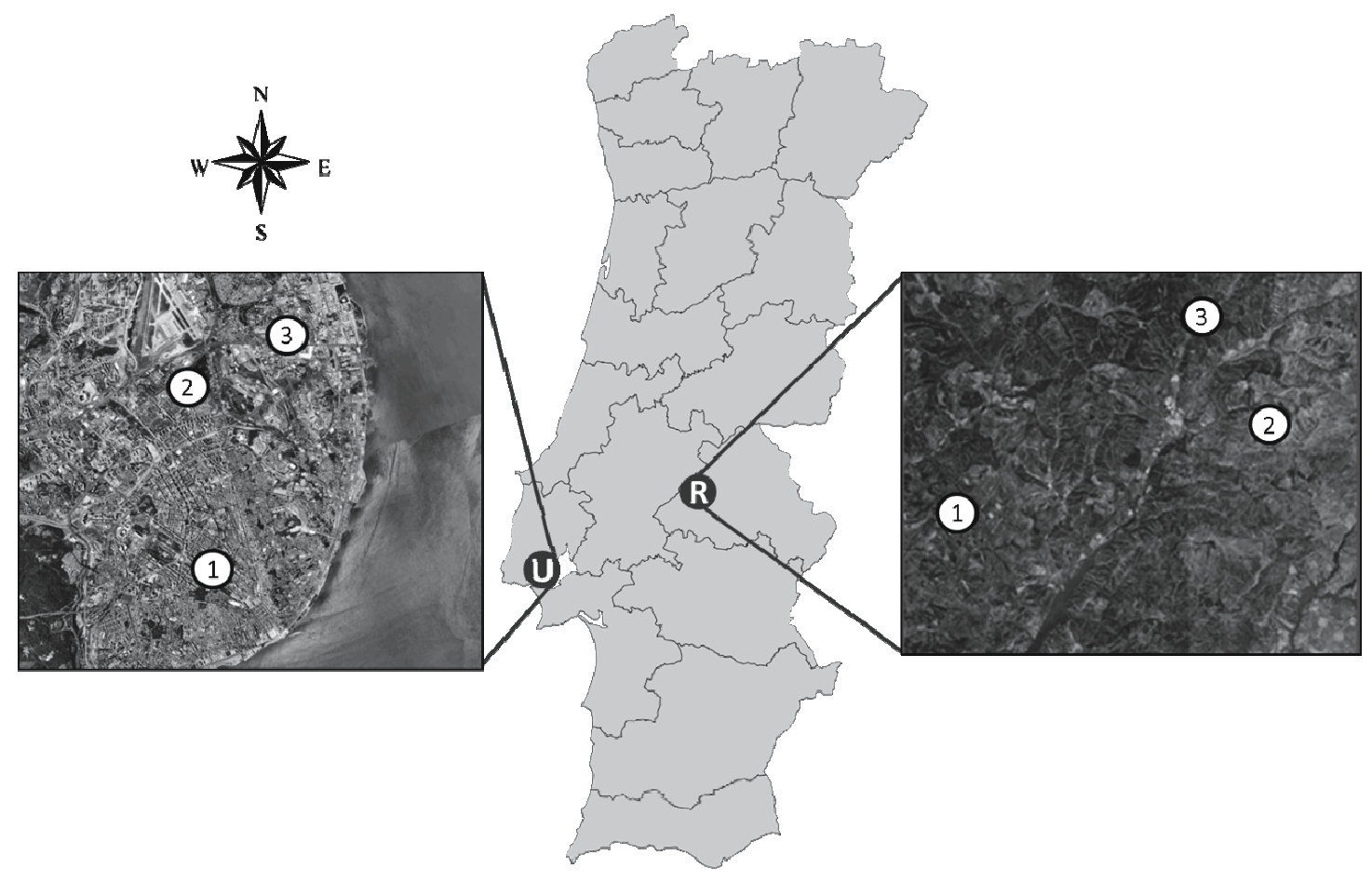

Fig. 1. Location of the studied primary schools at urban and rural areas 
Table 1. Summary of the characteristics of the studied schools and their classrooms A and B

\begin{tabular}{|c|c|c|c|c|c|c|}
\cline { 2 - 7 } \multicolumn{1}{c|}{} & \multicolumn{5}{c|}{ Urban } & \multicolumn{4}{c|}{ Rural } \\
\cline { 2 - 7 } \multicolumn{1}{c|}{} & \multicolumn{3}{c|}{ Primary Schools } \\
\hline Characteristics & $\mathrm{S} 1$ & $\mathrm{~S} 2$ & $\mathrm{~S} 3$ & $\mathrm{~S} 1$ & $\mathrm{~S} 2$ & $\mathrm{~S} 3$ \\
\hline Year of construction & 1970 & 1840 & 1961 & 1954 & 1980 & 1960 \\
\hline Classroom area, m (A/B) & $64.5 / 64.5$ & $50.0 / 50.0$ & $45.6 / 46.8$ & 48.4 & 45.0 & 40.5 \\
\hline Classroom height, m (A/B) & $3.7 / 3.7$ & $3.5 / 3.5$ & $3.5 / 3.5$ & 3.7 & 3.5 & 3.5 \\
\hline Nr Windows (A/B) & $8 / 8$ & $3 / 3$ & $6 / 6$ & 4 & 4 & 3 \\
\hline Window frame type & Aluminum & Aluminum & Wood & Wood & Aluminum & Aluminum \\
\hline Floor covering & Brick & Brick & Brick & Wood & Brick & Brick \\
\hline Visible mold (A/B) & Yes / No & No / No & No / No & No & No & No \\
\hline Direct Outdoor door & Yes & No & No & Yes & No & No \\
\hline Number of students (A/B) & $21 / 22$ & $22 / 21$ & $22 / 21$ & 20 & 11 & 12 \\
\hline
\end{tabular}

coated with a silicon solution (from Lanzoni), during $57-77$ days in the classroom indoors. The slides were placed at a height of about $1.8 \mathrm{~m}$ and three replicates per classroom were sampled. In the laboratory, the slides were stained with gelatin-fuchsin, covered with glasses and the pollens grains on $2.1 \mathrm{~cm}^{2}$ of the slide were counted using an Olympus BX60M Microscope $(20 \times$ lens). It was not possible to evaluate the outdoor levels of pollens because the silicon coat of the slide was overloaded with dust after each sampling period, turning impossible to count the pollen grains.

\section{Fungi and bacteria assessment}

Concerning fungi and bacteria assessment, two campaigns were conducted: in winter (sampled in February 2010) and in summer (sampled in June 2010), for both areas.

Two different sampling methods to collect fungi and bacteria were used: the active method and by passive deposition. For the active method, a MAS- $100^{\mathrm{TM}}$ air sampler device was used. Two different culture media in $90 \mathrm{~mm}$ Petri dishes were used: CRBA (Rose Bengal CAF Agar from Liofilchem) and TSA (Triptych Soy Agar from Merck) for fungi and bacteria, respectively. All samples were collected with the children inside the classrooms and at a height of $1.2 \mathrm{~m}$. A Petri dish with the desired media was placed in the air sampler which collected an air volume of $100 \mathrm{dm}^{3}$ during 1 minute. After sampling, the Petri dish was sealed with parafilm. A total of 3 replicates for fungi and bacteria in each sampling site were collected. Between samplings, the sampler "head" of the active sampler was cleaned using alcohol, and between schools the "head" was autoclaved.

For the passive method, sampling was performed simultaneously for both types of media. Both Petri dishes, containing the different media (TSA and CRBA) were opened simultaneously and exposed to room air for 15 minutes. Afterwards, the plates were closed and sealed with parafilm. This step was repeated until a total of three replicates for fungi and bacteria were achieved in each sampling site (classrooms and outdoor). The active method sampling was performed simultaneous with the passive sampling.

At the laboratory, the Petri dishes were stored in an inverted position (so that condensation does not influence the growth of the colonies) and were stored at room temperature. The number of colony forming units (CFU) was counted 7 days after sampling. Only the desired microorganisms were counted, namely fungi in CRBA and bacteria in TSA media, taking into account the characteristics of each type of colony.

Table 2. Temperature $(T)$ and relative humidity $(\mathrm{RH})$ values of outdoor air during the sampling campaigns of fungi and bacteria (data from IPMA)

\begin{tabular}{|c|c|c|c|c|}
\cline { 2 - 5 } \multicolumn{1}{c|}{} & \multicolumn{4}{c|}{ Sampling Campaign } \\
\cline { 2 - 5 } \multicolumn{1}{c|}{} & \multicolumn{2}{c|}{ Winter } & \multicolumn{2}{c|}{ Summer } \\
\hline Area & $\mathbf{T}\left({ }^{\circ} \mathbf{C}\right)$ & R.h. $(\%)$ & $\mathbf{T}\left({ }^{\circ} \mathbf{C}\right)$ & R.h. (\%) \\
\hline Urban & $13.0 \pm 1.8$ & $80.0 \pm 12.7$ & $21.3 \pm 2.1$ & $47.5 \pm 6.4$ \\
\hline Rural & $9.9 \pm 0.8$ & $97.5 \pm 1.3$ & $22.5 \pm 2.7$ & $39.8 \pm 4.5$ \\
\hline
\end{tabular}

Table 2 presents the temperature and relative humidity of the outdoor air during the sampling campaigns. Weather data was collected from the Portuguese Sea and Atmosphere Institute, I. P. (IPMA, IP).

\section{Statistical Treatment}

The variance of the results was performed by non-parametrics statistics for a significance level of 0.05, the Mann-Whitney for binary independent groups and Kruskal-Wallis for multiple dependent groups. All analyses were conducted using the software STATISTICA version 10.

\section{Results}

\section{Fungi}

Fungi concentrations measured in the indoor and outdoor of the studied schools by active and passive sampling methods are shown in Figures 2 and 3, respectively.

\section{Active Sampling}

The average indoor level of fungi measured in winter was $717 \mathrm{CFU} \cdot \mathrm{m}^{-3}$ while the outdoor average level was $1069 \mathrm{CFU} \cdot \mathrm{m}^{-3}$. 
Higher values for both indoor and outdoor environments were obtained for the summer period, with the fungi average concentration of 2248 and $2072 \mathrm{CFU} \cdot \mathrm{m}^{-3}$ for indoor and outdoor, respectively. The higher temperatures in the summer period are the main reason for the higher concentrations of fungi in both environments, since higher temperatures (near $25-30^{\circ} \mathrm{C}$ ) promote the fungal growth (Scheff et al. 2000).

The Portuguese legislation, defined by the National System for Energy and Indoor Air Quality Certification of Buildings (Regulamento dos Sistemas Energéticos de Climatização de Edifícios - RSECE 2006), concerning the indoor air quality at the buildings indoor stipulates a value of $500 \mathrm{CFU} \cdot \mathrm{m}^{-3}$ as the maximum limit value (MLV) for fungi and bacteria.

Results showed that, in summer, all classrooms exceeded the MLV and in winter only the urban school 3 and classroom B of urban school 1 presented concentration values below $500 \mathrm{CFU} \cdot \mathrm{m}^{-3}$.

The indoor concentrations of fungi were above the MLV in both studied seasons. These high levels of fungi measured in schools in the present study agree with other studies described in the literature in the past. Bates and Mahaffy (1996) investigated airbone fungi in 13 classrooms of 6 Florida schools during summer and it was found that outdoor concentrations were higher than the indoor ones. Indoor fungal levels ranged from 70 to $2000 \mathrm{CFU} \cdot \mathrm{m}^{-3}$ (mean value of $475 \mathrm{CFU} \cdot \mathrm{m}^{-3}$ ) while outdoor levels ranged from 340 to $4900 \mathrm{CFU} \cdot \mathrm{m}^{-3}$ (mean value of $1900 \mathrm{CFU} \cdot \mathrm{m}^{-3}$ ).

A study conducted in 96 classrooms in 38 randomly selected Swedish schools reported mean values of $500 \mathrm{CFU} \cdot \mathrm{m}^{-3}$ and maximum values of $4500 \mathrm{CFU} \cdot \mathrm{m}^{-3}$ (Smedje et al. 1997), with sampling periods between the months of March and June. Scheff et al. (2000) reported fungi concentrations of 561 and $811 \mathrm{CFU} \cdot \mathrm{m}^{-3}$ in a science room and in an art room, respectively, from an USA school.

For the active method, it was found that the results of the two studied seasons are significantly different $(p=0.00)$ for both indoor and outdoor environments, by the MannWhitney test. When comparing urban with rural clusters, only the outdoor values in winter are part of the same population $(\mathrm{p}=0.35)$ while all the other binaries groups are significantly different between themselves $(\mathrm{p}<0.05)$.

\section{Passive sampling}

The passive sampling method present a similar trend comparing with the results obtained with the active sampling method. As observed for the active sampling method, during the winter period all the outdoor fungi concentrations were higher than the indoor ones, for both areas. During the summer period, in the urban cluster only classroom A of the school 3 presented higher fungi concentration values than its outdoor (as observed by the active sampling method). For the rural cluster, all classrooms presented lower or equal fungi concentration values than their outdoor environments for both seasons. By the active sampling method, the results differed for the summer season in the rural cluster, since all the classrooms presented higher concentrations of fungi than the outdoor ones.

In winter the average indoor level of fungi was $3447 \mathrm{CFU} \cdot \mathrm{m}^{-2} \cdot \mathrm{h}^{-1}$ while the outdoor average value was of $18723 \mathrm{CFU} \cdot \mathrm{m}^{-2} \cdot \mathrm{h}^{-1}$. In summer, the average indoor value of

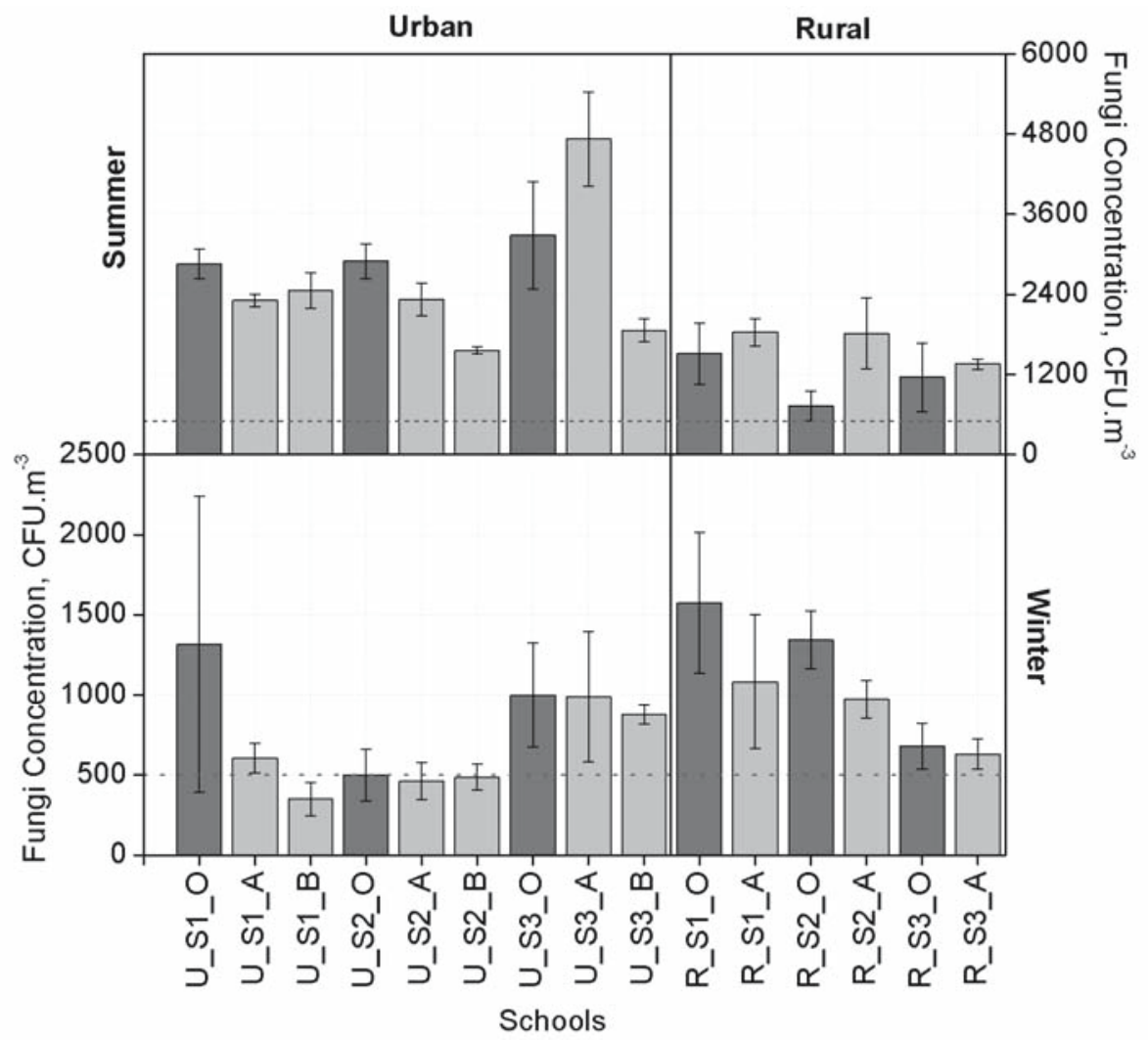

Fig. 2. Indoor and outdoor fungi concentrations in CFU $\mathrm{m}^{-3}$ for both seasons (winter and summer) and for urban and rural schools, obtained by the active sampling method. The dash line represents the limit value of $500 \mathrm{CFU} \cdot \mathrm{m}^{-3}$ defined by the Portuguese legislation for the indoor fungi concentration 
fungi was $12645 \mathrm{CFU} \cdot \mathrm{m}^{-2} \cdot \mathrm{h}^{-1}$ while the average outdoor value was $21098 \mathrm{CFU} \cdot \mathrm{m}^{-2} \cdot \mathrm{h}^{-1}$. As verified for the active sampling method, higher values were observed for the summer period for both types of environments, indoor and outdoor.

When comparing to other studies described in the literature, this study present similar results, namely higher averages of fungal colonies were counted in the summer than in the winter. Aydogdu et al. (2005) studied the fungi levels at 5 primary schools in Edirne city, Turkey, by the Petri Plate Gravitational Settling method, which is the passive method used in this study. The only difference was the sampling period of each plate, which was 10 minutes while in our study it was 15 minutes. The 15 minutes sampling period used in our work was chosen after a preliminary study to optimize the sampling periods. In the summer campaign, Aydogdu et al. (2005) registered minimum values of $943 \mathrm{CFU} \cdot \mathrm{m}^{-2} \cdot \mathrm{h}^{-1}$ and maximum values of $25465 \mathrm{CFU} \cdot \mathrm{m}^{-2} \cdot \mathrm{h}^{-1}$, with an average of $10375 \mathrm{CFU} \cdot \mathrm{m}^{-2} \cdot \mathrm{h}^{-1}$ in the indoors of the studied classrooms. In the winter, minimum values of $943 \mathrm{CFU} \cdot \mathrm{m}^{-2} \cdot \mathrm{h}^{-1}$ and maximum values of $25465 \mathrm{CFU} \cdot \mathrm{m}^{-2} \cdot \mathrm{h}^{-1}$ were observed, with an average of $5659 \mathrm{CFU} \cdot \mathrm{m}^{-2} \cdot \mathrm{h}^{-1}$ per classroom.

For the passive method, it was found that seasons are significantly different in the indoor results $(p=0.00)$, while for the outdoor results the two studied seasons are part of the same population $(\mathrm{p}=0.60)$. Comparing clusters, it was found a significant difference between urban and rural schools for both indoor and outdoor results in winter, while for summer the statistical results show that both urban and rural schools are part of the same population ( $p>0.05)$. This fact can be explained by a higher outdoor air penetration in the indoor environments in summer due to the higher frequency of the windows opening since all the classrooms had natural ventilation.

\section{Indoor/Outdoor ratios}

Figure 4 shows the seasonal I/O (indoor/outdoor) ratios for the two sampling methods and for both sampling seasons. In winter, $\mathrm{I} / \mathrm{O}$ ratios were lower than the unity which indicates that no fungal contamination exists from the outdoor environment to the indoor of the classrooms. In summer, the $\mathrm{I} / \mathrm{O}$ ratio $>$ 1 obtained from both methods for classroom A of urban school 3 indicates an indoor source of fungal contamination. The active sampling method showed that all rural classrooms also presented I/O ratios were higher than 1, which indicates a fungal contamination as well. However, the passive sampling method showed always I/O ratios lower or equal to 1 for all the rural classrooms.

The mean values of $\mathrm{I} / \mathrm{O}$ ratio by the passive method in winter were 0.20 and 0.26 for the urban and rural clusters, respectively. In summer, the mean values of the $\mathrm{I} / \mathrm{O}$ were 0.60 and 0.70 for the urban and rural clusters, respectively. Higher $\mathrm{I} / \mathrm{O}$ ratios were found by the active sampling method. The urban cluster registered mean $\mathrm{I} / \mathrm{O}$ ratios of 0.75 and 0.84 for winter and summer, respectively, and the rural cluster registered the $\mathrm{I} / \mathrm{O}$ ratios, 0.78 and 1.62 for winter and summer, respectively. Overall, the ratio of indoor to outdoor fungi concentration agrees with the ratio below 1 reported by Hussin et al. (2011), which suggests minimal indoor generative source of fungal bioaerosols. However, in our study the rural schools presented indoor generative source of fungal bioaerosols (I/O above 1).

\section{Bacteria}

Bacteria concentrations measured indoor and outdoor of the studied schools by active and passive sampling methods are shown by Figures 5 and 6 , respectively.

\section{Active Sampling}

The results from the active sampling method show that indoor values of bacteria concentration were higher than the outdoor results, for both sampling seasons. Only one exception to this trend was observed in classroom B of the urban school 1 in winter. Regarding the limit value of bacteria concentration in indoor environments regulated by the Portuguese legislation (RSECE 2006), which is $500 \mathrm{CFU} \cdot \mathrm{m}^{-3}$, it was observed that this value was reached beyond for most of the studied cases.

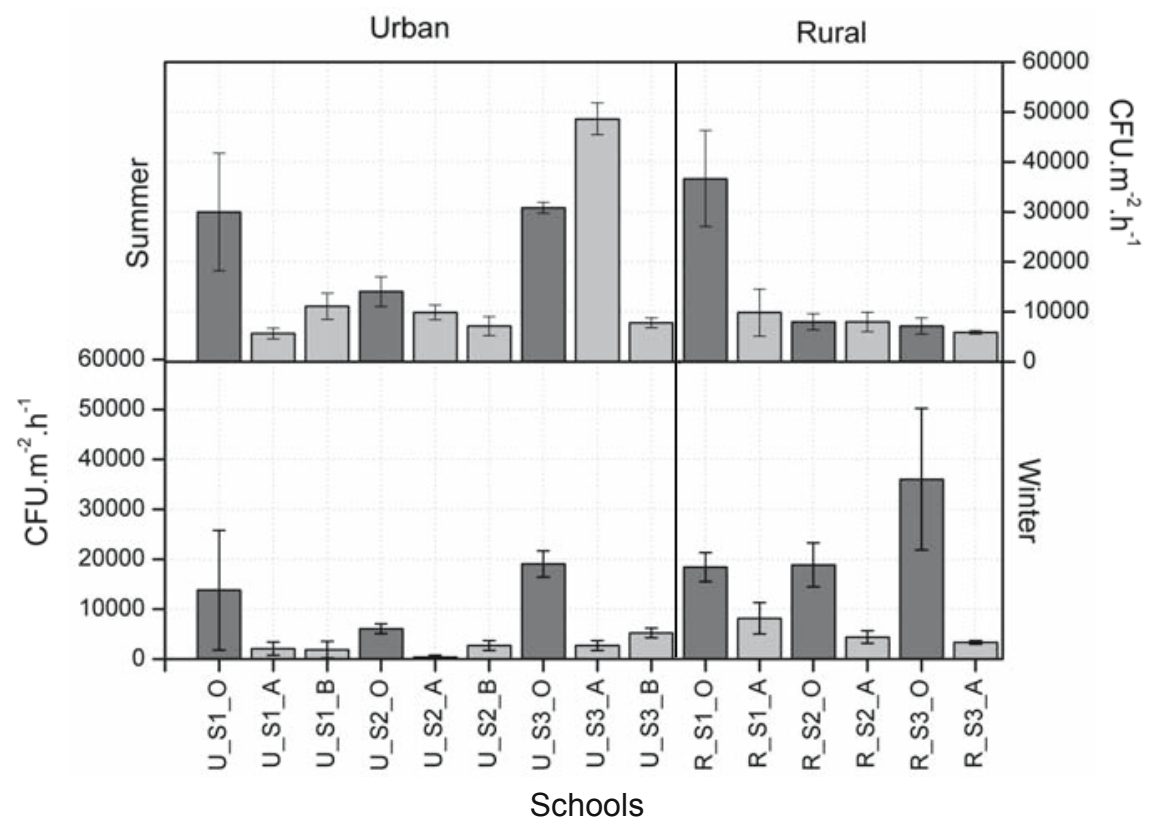

Fig. 3. Indoor and outdoor fungi levels (values in CFU. $\mathrm{m}^{-2} \cdot \mathrm{h}^{-1}$ ) for both seasons (winter and summer) and for urban and rural schools, obtained by the passive method 


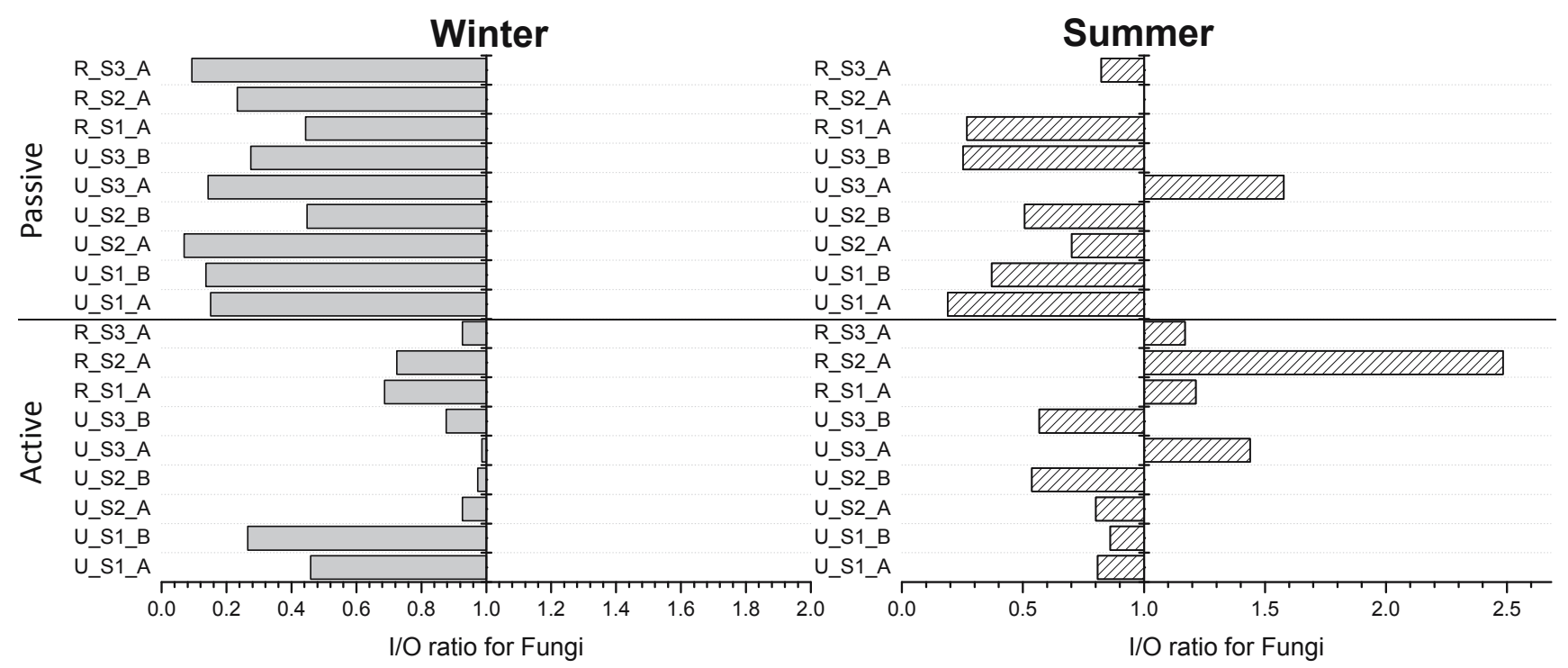

Fig. 4. Indoor/outdoor ratios of fungi determined by the passive (up) and the active (down) methods for the winter (left) and summer (right) seasons

In the rural cluster, the limit value of bacteria concentration was reached for all the studied classrooms, for both sampling seasons. In winter, the rural cluster registered a mean outdoor value of bacteria concentration of $201 \mathrm{CFU} \cdot \mathrm{m}^{-3}$ and a mean indoor value of $1984 \mathrm{CFU} \cdot \mathrm{m}^{-3}$, clearly exceeding the limit value of $500 \mathrm{CFU} \cdot \mathrm{m}^{-3}$ for indoor environments. In summer, the rural cluster registered higher values for both outdoor and indoor environments, namely, $539 \mathrm{CFU} \cdot \mathrm{m}^{-3}$ and $5105 \mathrm{CFU} \cdot \mathrm{m}^{-3}$, respectively.

For the urban cluster, all the studied classrooms registered bacteria concentrations higher than the limit value of $500 \mathrm{CFU} \cdot \mathrm{m}^{-3}$ in winter, while in summer only the classrooms $\mathrm{B}$ from schools 1 and 2 registered values below the limit value, which probably indicates a higher ventilation in these classrooms that contributed to avoid the indoor bacterial accumulation. For this cluster, in winter mean values of bacteria concentration of $441 \mathrm{CFU} \cdot \mathrm{m}^{-3}$ and $2784 \mathrm{CFU} \cdot \mathrm{m}^{-3}$ for outdoor and indoor environments, respectively, were registered. In summer, lower mean values of bacteria concentrations were measured, namely, $300 \mathrm{CFU} \cdot \mathrm{m}^{-3}$ and $2666 \mathrm{CFU} \cdot \mathrm{m}^{-3}$ for outdoor and indoor environments, respectively.

The rural cluster registered lower mean values of bacteria concentration in winter than the urban cluster, however in summer higher values were observed in the rural cluster.

The results of this study agree with the studies described in the literature. Daisey et al. (2003) conducted a review of several studies regarding the bacterial levels in indoor environment of schools and the reported range varied over two orders of magnitude, from $7 \mathrm{CFU} \cdot \mathrm{m}^{-3}$ to $19500 \mathrm{CFU} \cdot \mathrm{m}^{-3}$. Scheff et al. (2000) reported bacterial concentrations of 782 and $621 \mathrm{CFU} \cdot \mathrm{m}^{-3}$ in a science room and in an art room, respectively, from an USA school. Hussin et al. (2011) reported an average bacterial concentration of $1025 \pm 612 \mathrm{CFU} \cdot \mathrm{m}^{-3}$ and $1473 \pm 1261 \mathrm{CFU} \cdot \mathrm{m}^{-3}$ in indoor and outdoor air of 5 primary schools from Malaysia, respectively.

Regarding the active sampling method, the overall results obtained in the two studied seasons are not significantly different $(p>0.05)$, for both indoor and outdoor environments.
When comparing both urban and rural clusters, only the outdoor values in summer are significantly different between themselves $(p=0.01)$, while all the other binaries groups are part of the same population $(\mathrm{p}>0.05)$.

\section{Passive sampling}

Regarding the passive sampling method, the urban cluster registered higher values in indoor environments when comparing with outdoors for the summer season; while in winter, several classrooms showed lower values than the respective outdoor environment, namely classroom B of school 1 (as observed by the active sampling method), classroom B of school 2 and classroom A of school 3. In the rural cluster, the indoor bacteria levels were higher than outdoors for winter and summer, except for the classroom of school 1 in summer.

Higher values of bacteria counts were observed for the summer season for both clusters. Concerning the urban cluster, it was registered mean bacteria levels of 25430 and $28015 \mathrm{CFU} \cdot \mathrm{m}^{-2} \cdot \mathrm{h}^{-1}$ for indoor and outdoor environments, respectively, in winter and mean bacteria counts of 54562 and $36748 \mathrm{CFU} \cdot \mathrm{m}^{-2} \cdot \mathrm{h}^{-1}$ for indoor and outdoor environments, respectively, in summer. In the rural cluster, it was registered a mean value of bacteria counts of 20050 and $6986 \mathrm{CFU} \cdot \mathrm{m}^{-2} \cdot \mathrm{h}^{-1}$ for the indoor and outdoor environments, respectively, in winter and mean bacteria counts of 75591 and $50021 \mathrm{CFU} \cdot \mathrm{m}^{-2} \cdot \mathrm{h}^{-1}$ for the indoor and outdoor environments, respectively, in summer.

When comparing to other studies described in the literature, this study presents similar results that also showed higher mean values of bacterial counts in the winter period. Aydogdu et al. (2005) registered values of 943 and $93371 \mathrm{CFU} \cdot \mathrm{m}^{-2} \cdot \mathrm{h}^{-1}$ for the minimum and maximum values observed in the classrooms in summer, respectively. The mean value of bacterial colonies per school observed for the summer was $20749 \mathrm{CFU} \cdot \mathrm{m}^{-2} \cdot \mathrm{h}^{-1}$. In the winter period, minimum values of $7545 \mathrm{CFU} \cdot \mathrm{m}^{-2} \cdot \mathrm{h}^{-1}$ and maximum values of $55645 \mathrm{CFU} \cdot \mathrm{m}^{-2} \cdot \mathrm{h}^{-1}$ were observed, with a mean value of bacterial colonies per classroom of $30180 \mathrm{CFU} \cdot \mathrm{m}^{-2} \cdot \mathrm{h}^{-1}$. 


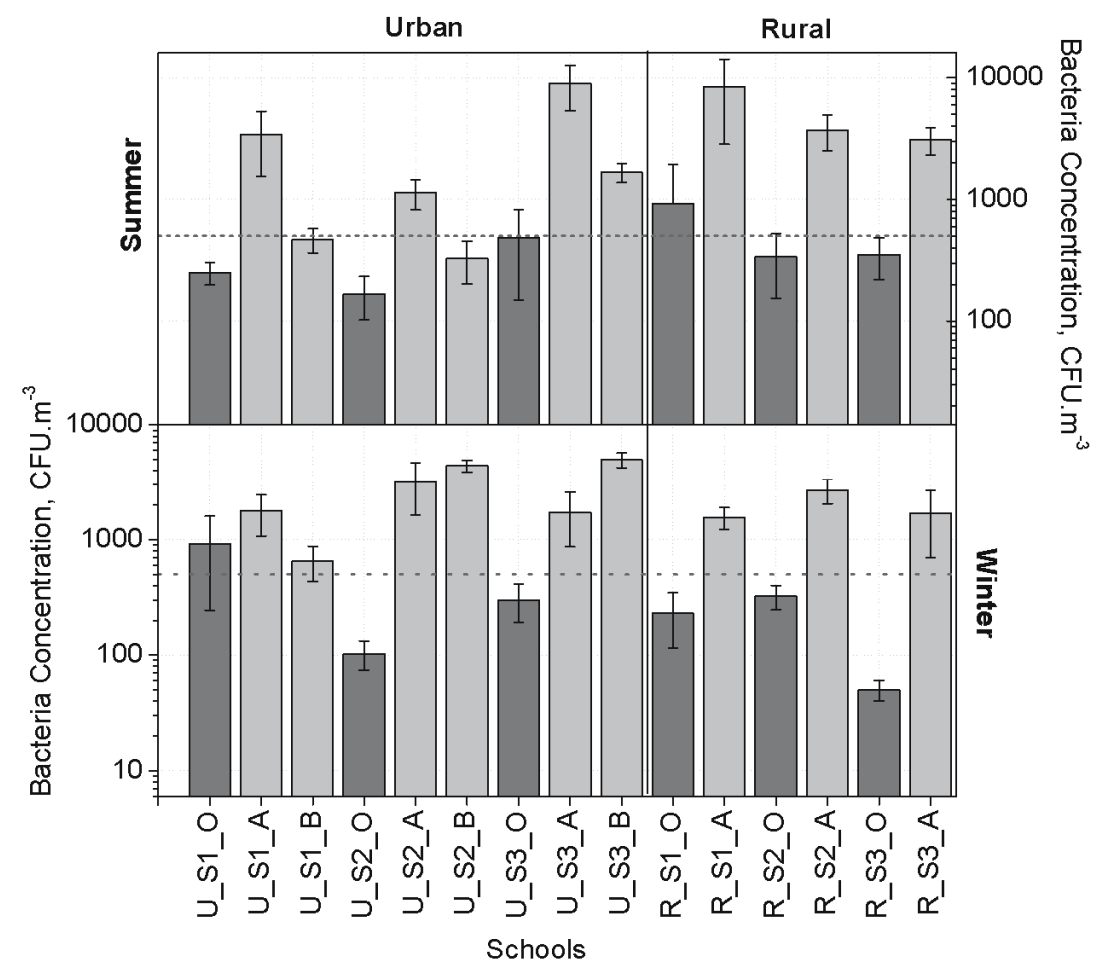

Fig. 5. Indoor and outdoor bacteria concentrations in CFU $\cdot \mathrm{m}^{-3}$ for both seasons (winter and summer) and for both urban and rural schools, obtained by the active sampling method. The dash line represents the limit value of $500 \mathrm{CFU} \cdot \mathrm{m}^{-3}$ defined by the Portuguese legislation for the indoor bacteria concentration

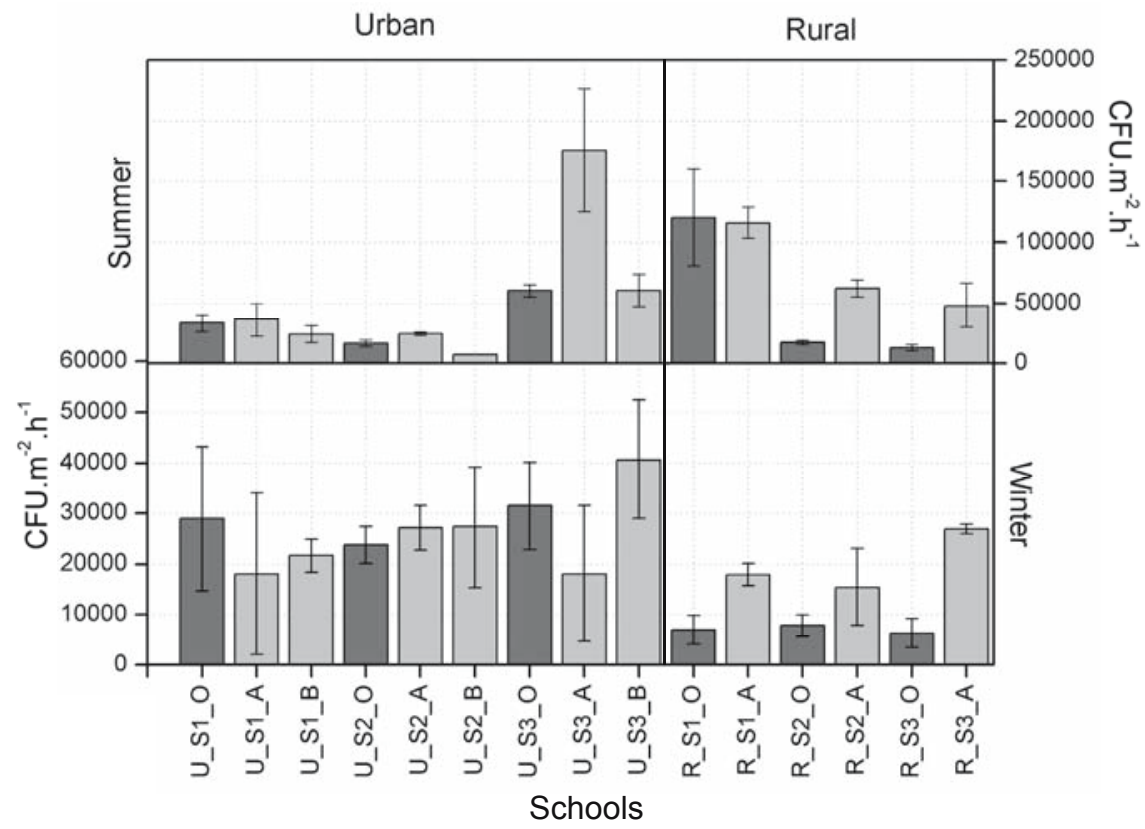

Fig. 6. Indoor and outdoor bacteria concentrations (values in CFU $\mathrm{m}^{-2} \cdot \mathrm{h}^{-1}$ ) for both seasons (winter and summer) and for both urban and rural schools, obtained by the passive method

For the passive method applied to the bacteria sampling, it was found a seasonal variation significantly different in the indoor and outdoor results $(\mathrm{p}<0.05)$. Regarding the comparison between clusters, only for winter was found a significantly difference between urban and rural schools for the outdoor results, while all the others binary groups showed to be part of the same population $(\mathrm{p}>0.05)$.

\section{Indoor/Outdoor ratios}

The seasonal I/O ratios for the two sampling methods are shown by Figure 7, for both sampling seasons.

In winter, $\mathrm{I} / \mathrm{O}$ ratios higher than 1 were observed for most of the studied classrooms, except for classroom B of urban school 1, by the active sampling method, and classrooms A and B of urban school 1 and classroom A of urban school 3, 

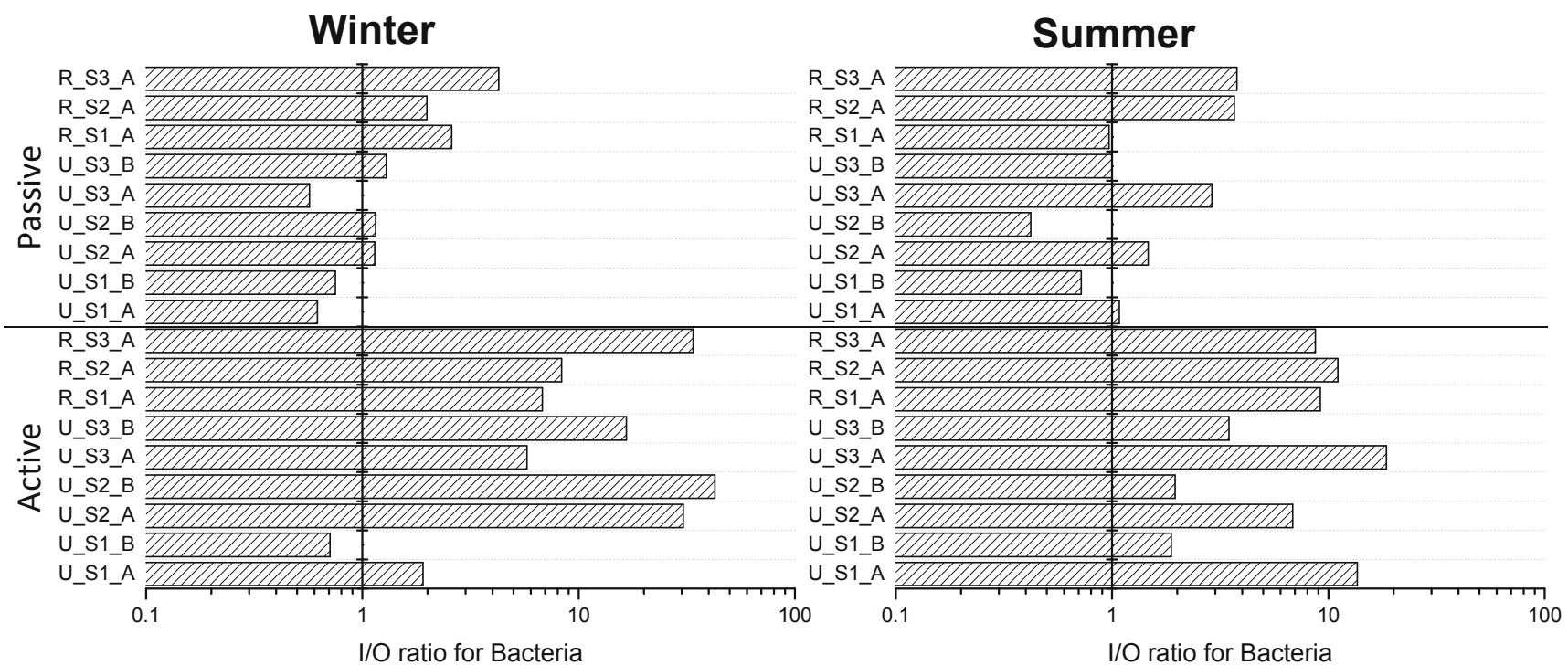

Fig. 7. Indoor/outdoor ratios of bacteria determined by the passive (up) and the active (down) methods for the winter (left) and summer (right) seasons

by the passive sampling method. In summer, only classroom B of urban school 1 and classroom B of urban school 3 registered $\mathrm{I} / \mathrm{O}$ ratios lower than 1 by the passive sampling method.

The mean values of $\mathrm{I} / \mathrm{O}$ ratio by the passive method in winter were 0.92 and 2.95 for the urban and rural clusters, respectively. In summer, the mean values of the I/O were 1.27 and 2.80 for the urban and rural clusters, respectively. Higher $\mathrm{I} / \mathrm{O}$ ratios were found by the active sampling method. The urban cluster registered mean I/O ratios of 16.38 and 7.72 for winter and summer, respectively. The rural cluster registered similar values of $\mathrm{I} / \mathrm{O}$ ratios, namely 16.33 and 9.66 for winter and summer, respectively. These higher values of I/O ratios are explained by the indoor source of bacteria that is the human presence.

\section{Correlations between methods}

Both sampling methods used in this study, the passive and the active, have been used widely in last decades to assess bioaerosols concentrations in indoor environments. The passive sampling, which main process is the sedimentation, is the easiest and the cheapest method. This method relies on the deposition of particles suspended in the air on surfaces coated with nutritive agar medium (open agar Petri dishes or slides) during a chosen time. Usually, the passive sampling is used in sites were the presence of bioaerosols is very sensitive, such as hospitals (Napoli et al. 2012). The main difference with the active sampling method is the need of a vacuum pump resulting in a known sampled air volume varying from about 10 to about $1500 \mathrm{~L} \cdot \mathrm{min}^{-1}$ (Mouilleseaux 1990) and, therefore, this sampling method is usually used as the reference method, concerning the established limit values in national and international guidelines and regulations.

In this study, the results from both sampling methods were compared and correlated to study the reliability and performance of the passive sampling method. Figures 8 and 9 show the linear correlations obtained for the studied seasons (winter and summer) and for both types of environments (indoor and outdoor) for the fungi and bacteria results, respectively.
Correlation coefficients were higher in the indoor environments ( $R>0.7$ for winter and $R>0.9$ for summer) than outdoors for both types of bioaerosols. The levels of bacteria measured in summer also presented a very good correlation $(\mathrm{R}>0.9)$ for the outdoor. This fact shows that, for indoor environments, the passive sampling method can be correlated with the active sampling method, which is used to assess fungi and bacteria concentrations required by national and international guidelines and legislation. Napoli et al. (2012) studied these correlations in operating rooms of hospitals and also registered high correlations between methods $(\mathrm{R}>0.9)$.

The lower correlation coefficient observed for outdoor results can be explained by air streams present in the outdoor environment that can influence greatly the deposition rate of fungi or bacteria by the passive deposition method.

\section{Pollens}

The seasonal variation of pollen concentration registered in the indoor of classrooms is shown in Figure 10. All classrooms had no indoor plants; therefore all the pollen grains found indoor were originated from an outdoor source.

Overall, in the urban area higher indoor amount of pollens were found in spring. This fact can be explained by the higher pollination that occurs in this season and by the higher frequency of opening of windows. The spring average pollen concentration was 2.3 pollens $\cdot \mathrm{cm}^{-2} \cdot$ day $^{-1}$, which was higher than in autumn and winter (1.5 and 0.7 pollens $\cdot \mathrm{cm}^{-2} \cdot$ day $^{-1}$, respectively). Autumn results show that natural ventilation by opening windows is still used since there is a significant variation of indoor pollen concentration in this season (in a range of 0.14 to 5.22 pollens $\mathrm{cm}^{-2} \cdot$ day $^{-1}$ ) within classrooms and schools. Classroom U_S3_A showed a higher concentration of pollen grains that can be explained by the proximity of the classroom to a higher number of trees in the area when compared with the other studied areas.

These results can indicate the influence of the natural ventilation since in the warmest seasons the opening of windows is often used by the teachers due to the comfortable 

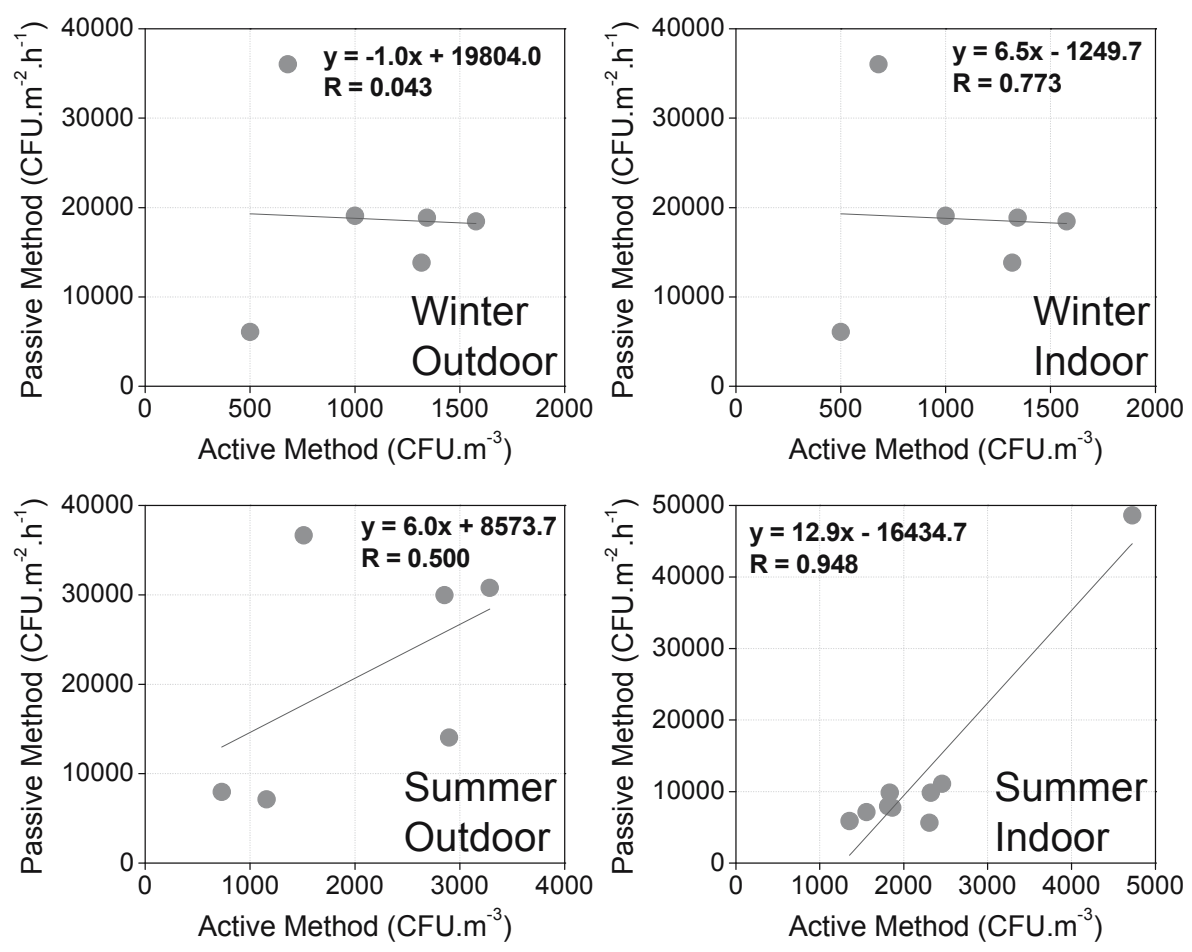

Fig. 8. Linear correlations between sampling methods (active and passive) for both seasons (winter and summer) and environments (indoor and outdoor) for results of fungi
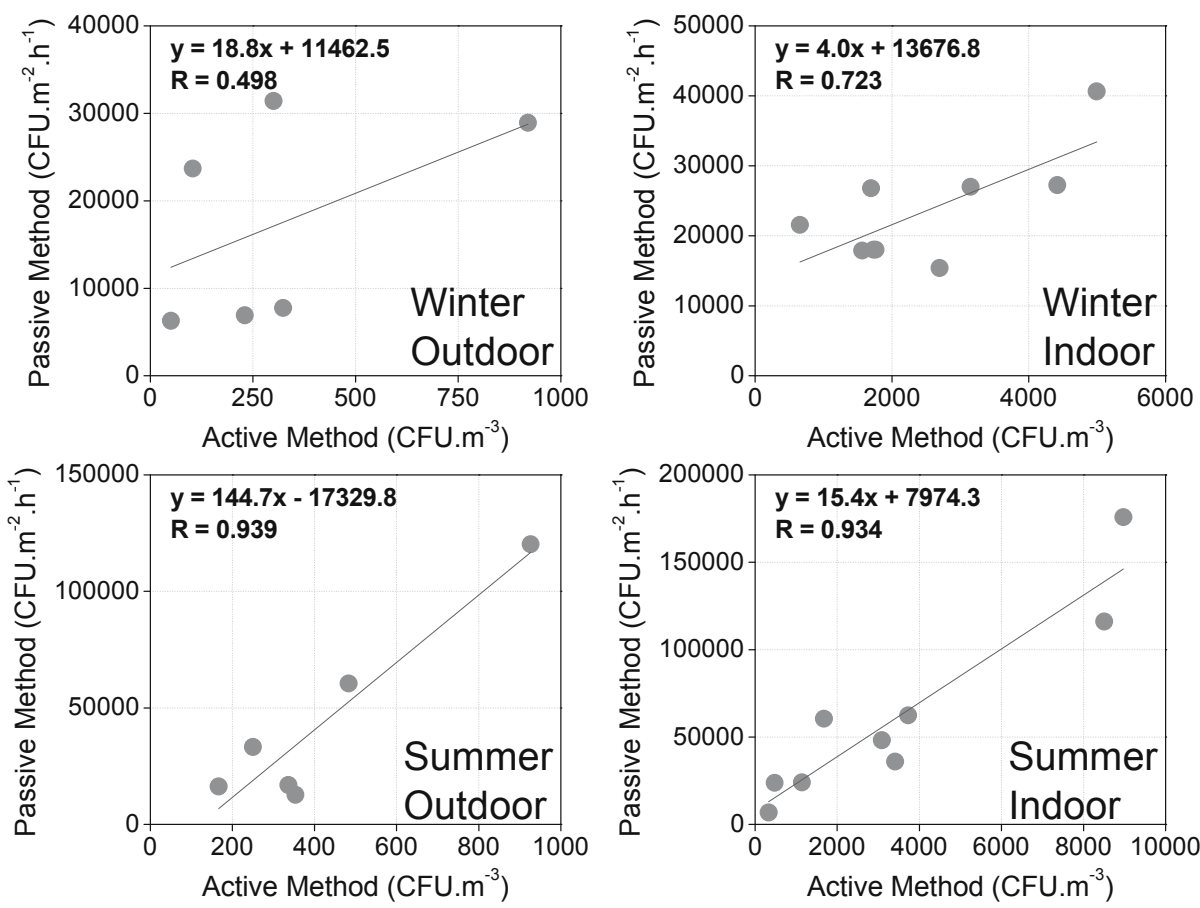

Fig. 9. Linear correlations between sampling methods (active and passive) for both seasons (winter and summer) and environments (indoor and outdoor) for results of bacteria

outdoor atmospheric conditions. Winter results show lower pollen concentrations, very similar in all the classrooms, only with a deviation of $18 \%$ from the winter average concentration. This fact agrees with the assumption that windows are not opened in winter due to the outdoor atmospheric conditions, which leads to very low ventilation rates inside the classrooms (Canha et al. 2013b).
Mann-Whitney test showed that the datasets of autumn and winter are part of the same population ( $\mathrm{p}$-value of 0.850 ), while the other binaries with spring (spring/autumn and spring/winter) are significantly different between themselves (p-value lower than 0.050). With the Kruskal-Wallis test, the results showed significant differences between seasonal pollen concentrations $(p=0.000)$. 


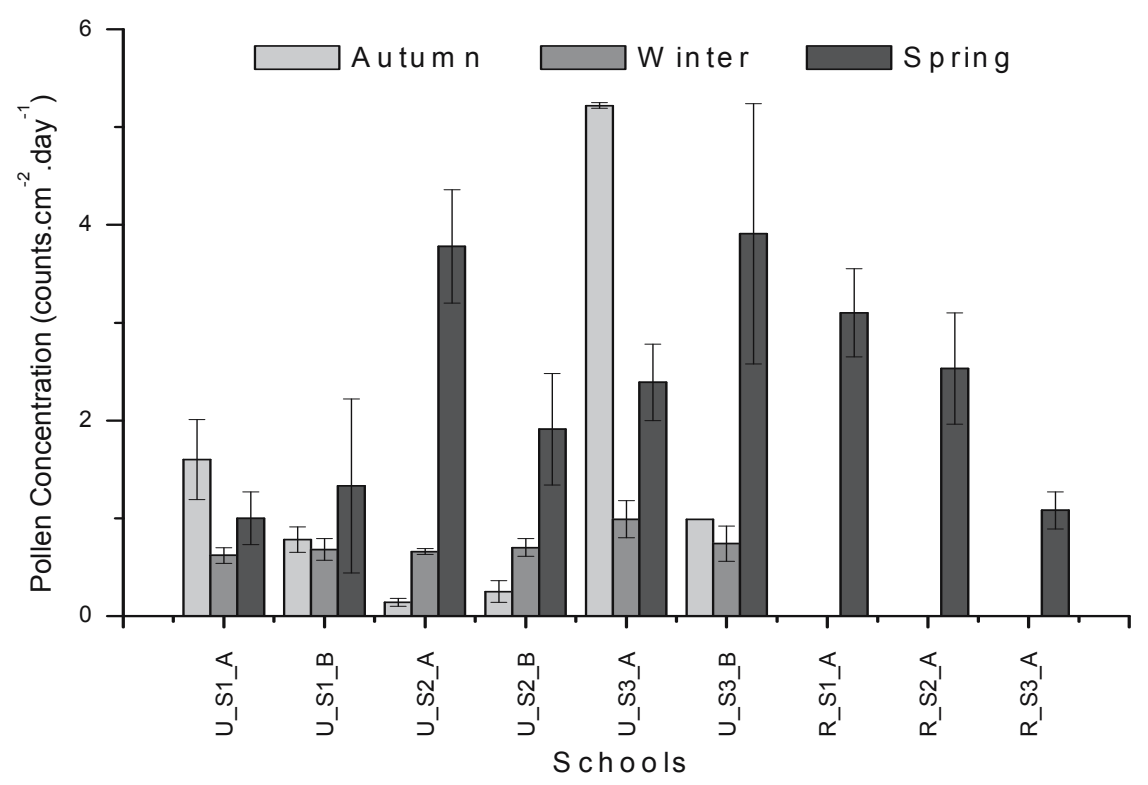

Fig. 10. Seasonal variation of the indoor pollen concentrations in the studied classrooms $(U-$ urban cluster, $\mathrm{R}$ - rural cluster; $\mathrm{S}$ - school; A - classroom A and B - classroom B)

The statistical difference between clusters was also studied for spring by the Mann-Whitney test and it was obtained a p-value of 0.939 , which means that there is no significant difference between the results obtained in both clusters, urban and rural. For each season, it was also studied the significant difference between the results of the two classrooms within the same school by the Mann-Whitney test. Results showed that all classrooms within the same school and for all seasons are part of the same population, which shows that the classrooms of a same school are conditioned by the outdoor conditions, namely, in terms of outdoor vegetation.

\section{Discussion}

Fungi concentrations were higher in outdoor environments and in the summer period, due to the outdoor atmospheric conditions, especially temperature and relative humidity, which condition their growth. During summer, $100 \%$ of the urban and rural studied classrooms showed values higher than the mandatory MLV and, in winter, all the rural schools presented concentration values higher than MLV, although only $50 \%$ of the urban classrooms showed concentrations exceeding the MLV. Indoor to outdoor ratios were always lower than 1 in winter, which shows that there was not any relevant indoor fungal source in these classrooms. In summer, $\mathrm{I} / \mathrm{O}$ ratios higher than one were found for the rural classrooms and one urban classroom showing the existence of an indoor source of fungi.

Bacteria levels were higher in the indoor of the classrooms due to the children presence as shown by an $\mathrm{I} / \mathrm{O}$ ratio generally above 1 . In winter, all classrooms showed bacteria concentrations above the MLV which reflects that the ventilation is not enough to avoid the indoor bacterial accumulation. In summer, 3 classrooms showed bacterial concentrations below the MLV which is the consequence of a higher frequency of opening windows due to the outdoor atmospheric conditions. No significant differences between clusters were found. The bacteria levels of the classrooms indoor reflect the different patterns of the ventilation, such as the frequency and duration of keeping windows open. The indoor bacterial level is specially associated with the occupancy of the classroom and insufficient ventilation. Therefore, increasing and improving the ventilation by means of mechanical or natural systems can play a key role in improving the indoor air quality (Canha et al. 2015), since it can avoid the bacterial accumulation at the indoor environments.

The indoor pollen levels indicate that ventilation has a major role in the indoor contamination. Results showed that the indoor seasonal average of pollen counts was significantly different between spring and autumn/winter. However, between autumn and winter, the averages were not significantly different due probably to a similar ventilation pattern in both seasons. Spring showed the highest pollen concentrations while the lowest values were found in winter. Statistical differences between clusters were not found.

The passive method used in this work for the fungi and bacterial sampling, also known as the Petri dish exposure method or settling method (Aydogdu et al. 2005, Cabral 2010) has several inherent practicalities, such as, the easy use, low cost and the not need of specific and expensive sampling equipment (Canha et al. 2010b). This method can be recommended to obtain preliminary or qualitative information. Very good correlations between both sampling methods (active and passive) for fungi and bacteria were found in this work, although passive method has a disadvantage of not being volumetric nor quantitative.

Moreover, the size of bio-aerosols particles can also be a bias factor in the passive sampling method because larger particles have a rapid settling rate, which conduct to a not real sampling of all particles available in the air since the lighter particles are not correctly sampled. By the other hand, sampling in turbulent air is seriously affected by shadowing or turbulent deposition which can explain the lower correlations between methods observed in this study in the outdoor environments, 
where is typical higher probability of turbulence air.

\section{Conclusion}

The indoor concentrations of three different types of bioaerosols (pollens, fungi and bacteria) were assessed in primary schools of two types of clusters (urban and rural) in different seasons of the year. Passive and active sampling methodologies were applied simultaneously to assess bacterial and fungal concentrations in both indoor and outdoor environments, which allowed determining the I/O ratios. Passive method allowed obtaining qualitative results that correlated well in indoor environments with the active method.

The present study allowed to assess the levels of indoor bioaerosols at primary schools in urban and rural areas, which can help to characterize the children inhalation exposure to these bioaerosols in scholar environments.

\section{Acknowledgements}

N. Canha thanks Fundação para a Ciência e a Tecnologia (FCT; Portugal) for his Pos-Doctoral grant (SFRH/BPD/102944/2014). $\mathrm{C}^{2} \mathrm{TN} / \mathrm{IST}$ authors gratefully acknowledge the FCT support through the UID/Multi/04349/2013 project. We are grateful for the cooperation and participation in this study of all the schools, their staff, teachers and students.

\section{References}

Almeida, S.M., Freitas, M.C., Repolho, C., Dionísio, I., Dung, H.M., Pio, C.A., Alves, C., Caseiro, A. \& Pacheco, A.M.G. (2009a). Evaluating children exposure to air pollutants for an epidemiological study, Journal of Radioanalytical and Nuclear Chemistry, 280, 2, pp. 405-409.

Almeida, S.M., Freitas, M.C., Repolho, C., Dionisio, I., Dung, H.M., Caseiro, A., Alves, C., Pio, C.A. \& Pacheco, A.M.G. (2009b). Characterizing air particulate matter composition and sources in Lisbon, Portugal, Journal of Radioanalytical and Nuclear Chemistry, 281, 2, pp. 215-218.

Almeida, S.M., Canha, N., Silva, A., Freitas, M.C., Pegas, P., Alves, C., Evtyugina, M. \& Pio, C.A. (2011). Children exposure to atmospheric particles in indoor of Lisbon primary schools, Atmospheric Environment, 45, pp. 7594-7599.

Almeida, S.M., Lage, J., Freitas, M.C., Pedro, A.I., Ribeiro, T., Silva, A.V., Canha, N., Almeida-Silva, M., Sitoe, T., Dionisio, I., Garcia, S., Domingues, G., Faria, J.P., Fernández, B.G., Ciaparra, D. \& Wolterbeek, H.T. (2012). Integration of biomonitoring and instrumental techniques to assess the air quality in an industrial area located in the coastal of Central Asturias, Spain, Journal of Toxicology and Environmental Health, Part A: Current Issues, 75, 22-23, pp. 1392-1403.

Almeida, S.M., Silva, A.I., Freitas, M.C., Dzung, H.M. Caseiro, A. \& Pio, C.A. (2013). Impact of maritime air mass trajectories on the western European coast urban aerosol, Journal of Toxicology and Environmental Health, Part A: Current Issues, 76, 4-5, pp. 252-262.

Almeida-Silva, M., Canha, N., Galinha, C., Dung, H.M., Freitas, M.C. \& Sitoe, T. (2011a). Trace elements in wild and orchard honeys, Applied Radiation and Isotopes, 69, 11, pp. 1592-1595.

Almeida-Silva, M., Canha, N., Freitas, M.C., Dung, H.M. \& Dionísio, I. (2011b). Air pollution at an urban traffic tunnel in Lisbon, Portugal - an INAA study, Applied Radiation and Isotopes, 69, 11, pp. 1586-1591.
Almeida-Silva, M., Wolterbeek, H.Th. \& Almeida, S.M. (2014a). Elderly exposure to indoor air pollutants, Atmospheric Environment, 85, pp. 54-63.

Almeida-Silva, M., Almeida, S.M., Gomes, J.F., Albuquerque, P.C. \& Wolterbeek, H.T. (2014b). Determination of airborne nanoparticles in elderly care centers, Journal of Toxicology and Environmental Health, Part A: Current Issues, 77, 14-16, pp. 867-878.

Almeida-Silva, M., Almeida, S.M., Pegas, P.N., Nunes, T., Alves, C.A. \& Wolterbeek, H.T. (2015). Exposure and dose assessment to particle components among na elderly population, Atmospheric Environment, 102, pp. 156-166.

Aydogdu, H., Asan, A., Otkun, M.T. \& Ture, M. (2005). Monitoring of fungi and bacteria in the indoor air of primary schools in Edirne city, Turkey, Indoor and Built Environment, 14, 5, pp. 411-425.

Bates, J.M. \& Mahaffy, D.J. (1996). Relationships of reported allergy symptoms, relative humidity and airborne biological in thirteen Florida classrooms, Proceedings of Indoor Air '96: The 7th International Conference on Indoor Air Quality and Climate, Nagoya, Japan, 1, pp. 551-556.

Bejan, A., Dincer, I., Lorente, S., Miguel, A.F. \& Reis, A.H. (2004). Porous and Complex Flow Structures in Modern Technologies, Springer-Verlag, New York, 2004.

Burge, H. (1995). Bioaerosols, Lewis Publishers, Boca Raton 1995.

Cabral, J.P.S. (2010). Can we use indoor fungi as bioindicators of indoor air quality? Historical perspectives and open questions, Science of the Total Environment, 408, 20, pp. 4285-4295.

Canha, N., Freitas, M.C., Anawar, H.M., Dionisio, I., Dung, H.M., Pinto-Gomes, C. \& Bettencourt, A. (2010a). Characterization and phytoremediation of abandoned contaminated mining area in Portugal by INAA, Journal of Radioanalytical and Nuclear Chemistry, 286, 2, pp. 577-582.

Canha, N., Freitas, M.C., Almeida, S.M., Almeida, M., Ribeiro, M., Galinha, C. \& Wolterbeek, H.T. (2010b) Indoor school environment: easy and low cost to assess inorganic pollutants, Journal of Radioanalytical and Nuclear Chemistry, 286 (2), 495-500.

Canha, N., Almeida, M., Freitas, M. C. \& Almeida, S.M. (2011). Seasonal variation of total particulate matter and children respiratory diseases at Lisbon basic schools using passive methods, Procedia Environmental Sciences, 4, pp. 170-183.

Canha, N., Almeida-Silva, M., Freitas, M.C., Almeida, S.M. \& Wolterbeek, H.T. (2012a). Lichens as biomonitors at indoor environments of primary schools, Journal of Radioanalytical and Nuclear Chemistry, 291, 1, pp. 123-128.

Canha, N., Martinho, M., Almeida-Silva, M., Freitas, M.C., Almeida, S.M., Pegas, P., Alves, C., Pio, C., Trancoso, M., Sousa, R., Mouro, F. \& Contreiras, T. (2012b). Indoor air quality in primary schools, International Journal of Environment and Pollution, 50, 1/2/3/4, pp. 396-410.

Canha, N., Freitas, M.C., Almeida-Silva, M., Almeida, S.M., Dung, H.M., Dionísio, I., Cardoso, J., Pio, C.A., Caseiro, A., Verburg, T.G. \& Wolterbeek, H.T. (2012c). Burn Wood influence on outdoor air quality in a small village: Foros de Arrão, Portugal, Journal of Radioanalytical and Nuclear Chemistry, 291, 1, pp. 83-88.

Canha, N., Freitas, M.C. \& Pacheco, A.M.G. (2013a). Response of airpollution biomonitors under three different meteorological conditions, Journal of Radioanalytical and Nuclear Chemistry, 295, 1, pp. 489-496.

Canha, N., Almeida, S.M., Freitas, M.C., Täubel, M. \& Hänninen, O. (2013b). Winter ventilation rates at primary schools: comparison between Portugal and Finland, Journal of Toxicology and Environmental Health, Part A: Current Issues, 76, 6, pp. 1-8. 
Canha, N., Almeida, S.M., Freitas, M.C., Trancoso, M., Sousa, A., Mouro, F. \& Wolterbeek, H.T. (2014a) Particulate matter analysis in indoor environments of urban and rural primary schools using passive sampling methodology, Atmospheric Environment, 83, pp. 21-34.

Canha, N., Almeida, S.M., Freitas, M.C. \& Wolterbeek, H.T. (2014b) Indoor and Outdoor Biomonitoring using Lichens at Urban and Rural Primary Schools. Journal of Toxicology and Environmental Health, Part A: Current Issues, 77, 14-16, pp. 900-915.

Canha, N., Almeida, S.M., Freitas, M.C., Wolterbeek, H.T., Cardoso, J., Pio, C.A. \& Caseiro, A. (2014c). Impact of wood burning on indoor $\mathrm{PM}_{2.5}$ in a primary school in rural Portugal, Atmospheric Environment, 94, pp. 663-670.

Canha, N., Mandin, C., Ramalho, O., Wyart, G., Ribéron, J., Dassonville, C., Hänninen, O., Almeida, S.M. \& Derbez, M. (2015). Assessment of ventilation and indoor air pollutants in nursery and elementary schools in France, Indoor Air Journal (in press), doi: 10.1111/ina.12222

Dacarro, C., Picco, A.M., Grisoli, P. \& Redolfi, M. (2003). Determination of aerial microbiological contamination in scholastic sports environment, Journal of Applied Microbiology, 95, 5, pp. 904-912.

Daisey, J.M., Angell, W.J. \& Apte, M.G. (2003). Indoor air quality, ventilation and health symptons in schools: an analysis of existing information, Indoor Air, 13, 1, pp. 53-64.

Hussin, N.H.M., Sann, L.M., Shamsudin, M.N. \& Hashim, Z. (2011). Characterization of bacteria and fungi bioaerosol in the indoor air of selected primary schools in Malaysia, Indoor and Built Environment, 20, 6, pp. 607-617.

Husman, T. (1996). Health effects of indoor-air microorganisms, Scandinavian Journal of Work, Environment \& Health, 22, 1, pp. 5-13.

Jantunen, M., Jaakkola, J.J.K. \& Krzyzanowski, M. (1997). Assessment of exposure to indoor air pollutants, WHO Regional Publications, European Series, no. 78, WHO, Copenhagen 1997.

Kosonen, R. \& Tan, F. (2004). The effect of perceived indoor air quality on productivity loss, Energy Buildings, 36, 10, pp. 981-986.

Lage, L., Almeida, S.M., Reis, M.A., Chaves, P.C., Ribeiro, T., Garcia, S., Faria, J.P., Fernandez, B.G. \& Wolterbeek, H.T. (2014). Levels and spatial distribution of airborne chemical elements in a heavy industrial area located in the north of Spain, Journal of Toxicology and Environmental Health, Part A: Current Issues, 77, pp. 856-866.

Macher, J.M. (1999). Bioaerosols: Assessment and control, American Conference of Governmental Industrial Hygienists, Cincinnati 1999.

Mouilleseaux, A. (1990). Sampling methods for bioaerosols, Aerobiologia, 6, pp. 32-35.

Morawska, L., Afshari, A., Bae, G.N., Buonanno, G., Chao, C.Y.H., Hänninen, O., Hofmann, W., Isaxon, C., Jayaratne, E.R., Pasanen, P., Salthammer, T., Waring, M. \& Wierzbicka, A. (2013). Indoor aerosols: from personal exposure to risk assessment, Indoor Air, 23, 6, pp. 462-487.

Napoli, C., Marcotrigiano, V. \& Montagna, M.T. (2012). Air sampling procedures to evaluate microbial contamination: a comparison between active and passive methods in operating theatres, BMC Public Health, 12, pp. 594.

Pastuszka, J.S., Paw, U.K.T., Lis, D.O., Wlazlo, A. \& Ulfig, K. (2000). Bacterial and fungal aerosol in indoor environment in Upper Silesia, Poland, Atmospheric Environment, 34, pp. 3833-3842.

Pegas, P.N., Evtyugina, M.G.,Alves, C. A., Nunes, T., Cerqueira, M., Franchi, M., Pio, C., Almeida, S.M. \& Freitas, M.C. (2010). Outdoor/indoor air quality in primary schools in Lisbon: a preliminary study, Quimica Nova, 33, pp. 1145-1149.

Pegas, P.N., Alves, C.A., Evtyugina, M.G., Nunes, T., Cerqueira, M., Franchi, M., Pio, C.A., Almeida, S.M., Cabo Verde, S. \& Freitas, M.C. (2011a). Seasonal evaluation of outdoor/indoor air quality in primary schools in Lisbon, Journal of Environmental Monitoring, 13, 3, pp. 657-667.

Pegas, P.N., Alves, C.A., Evtyugina, M.G., Nunes, T., Cerqueira, M., Franchi, M., Pio, C.A., Almeida, S.M. \& Freitas, M.C. (2011b). Indoor air quality in elementary schools of Lisbon in spring, Environmental Geochemistry and Health, 33, 5, pp. $455-468$.

Ramos, C.A., Wolterbeek, H.T. \& Almeida, S.M (2014). Exposure to indoor air pollutants during physical activity in fitness centers, Building and Environment, 82, pp. 349-360.

RSECE (2006). Regulamento dos Sistemas Energéticos de Climatização em Edifícios (RSECE) - Decreto-Lei no. 79/2006, de 04/04/2006, Ministério das Obras Públicas, Transportes e Comunicações, Portugal 2006.

Selgrade, M.K., Plopper, C.G., Gilmour, M.I., Conolly, R.B. \& Foos, B.S.P. (2008). Assessing the health effects and risks associated with children's inhalation exposures - Asthma and allergy, Journal of Toxicology and Environmental Health, Part A: Current Issues, 71, 3, pp. 196-207.

Scheff, P.A., Paulius, V.K., Curtis, L. \& Conroy, L.M. (2000). Indoor air quality in a middle school, Part II: Development of emission factors for particulate matter and bioaerosols, Applied Occupational and Environmental Hygiene, 15, 11, pp. 835-842.

Smedje, G., Norback, D., \& Edling, C. (1997). Subjective indoor air quality in schools in relation to exposure, Indoor Air, 7, 2, pp. 143-150.

Srikanth, P., Sudharsanam, S. \& Steinberg, R. (2008). Bio-aerosols in indoor environment: composition, health effects and analysis, Indian Journal of Medical Microbiology, 26, 4, pp. 302-312.

Trancoso, M., Sousa, A., Mouro, F., Freitas, M.C., Almeida, S. \& Canha, N. (2012). Indoor air quality: validation and setting up quality control for determination of anions and cations in particulate matter, Accreditation and Quality Assurance, 17, 2, pp. 199-206.

Viegas, C., Almeida-Silva, M., Gomes, A.Q., Wolterbeek, H.T. \& Almeida, S.M. (2014). Fungal Contamination assessment in Portuguese elderly care centers, Journal of Toxicology and Environmental Health, Part A: Current Issue, 77, 1-3, pp. 14-23.

Wilson, R. \& Spengler, J. (1996). Particles in Our Air: Concentrations and Health Effects. Harvard University Press, Boston 1996. 